\title{
Political Administration
}

\author{
Åkerstrøm Andersen, Niels
}

Document Version

Final published version

Publication date:

2000

License

CC BY-NC-ND

Citation for published version (APA):

Ảkerstrøm Andersen, N. (2000). Political Administration. Department of Management, Politics and Philosophy, CBS. MPP Working Paper No. 5/2000

Link to publication in CBS Research Portal

\section{General rights}

Copyright and moral rights for the publications made accessible in the public portal are retained by the authors and/or other copyright owners and it is a condition of accessing publications that users recognise and abide by the legal requirements associated with these rights.

\section{Take down policy}

If you believe that this document breaches copyright please contact us (research.lib@cbs.dk) providing details, and we will remove access to the work immediately and investigate your claim. 


\section{Political Administration}

\section{Niels Åkerstrøm Andersen}

WP 5/2000

A pril 2000 
MPP Working Paper No. 5/2000 @

April 2000

ISBN: $\quad$ 87-90403-73-8

ISSN: $\quad 1396-2817$

Department of Management, Politics and Philosophy

Copenhagen Business School

Blaagaardsgade 23B

DK-2200 Copenhagen N

Denmark

Phone: +4538153630

Fax: $\quad+4538153635$

E-mail: as.lpf@cbs.dk

http://www.cbs.dk/departments/mpp 


\title{
Political Administration
}

\author{
By Niels Åkerstrem Andersen
}

\section{Introduction}

One of the major discussions of the 1990s has been about the relation between politics and administration. The themes of the discussions have been many and varied. It has been suggested that the level of politics should concentrate on the general political outlining and entrust the remaining to the administration. It has been criticised that politicians make their decisions on the basis of single cases, which ought to be an administrative matter entirely. It has been a theme that efficient operations can be created only by creating a clear difference between politics and administration. These questions have been raised in most of the OECD countries and the general headline given has been: "New Public Management." The same situation appeared in D enmark, which provided the case on which this article is based.

The thing that triggered my curiosity was a line of statements made by the Danish Ministry of Finance. The D anish Ministry of Finance has time and again problematised the political. The Ministry of Finance has been in the lead of many reforms and concrete initiatives with the purpose of getting the political drawn back in relation to the administrative, and give the public institutions the independence to make a number of dispositions free of political interference. Among others one may mention the transformation of state institutions into state PLC's, leasings, contract management etc. The concept of "excessive control" has been mentioned and so has arguments concerning that the politicians should concentrate on the general and "genuine political," and that the relation between political and administrative institutions should be changed from being a relation of hierarchy to a relation of dialogue and mutuality, where the political only decides in last resort.

It occurs to me that what we are facing here is an administration (the Danish Ministry of Finance) that politicises the politics' relation to the administration. We have to do with an administration that has arrogated to itself the right to question the relation between administration and politics, and suggest the initiation of policies on how things should be as well. It seems like a paradox: politics are intensified in the administration when the administration (in this case the Ministry of Finance) attempts to delimit, and free the administration of, the political. How did this become a possibility and in what way does it change the political system? That is the centre of this article.

The purpose of the article is not to determine where the line between politics and administration should be drawn. It does not form a normative critique of neither the New Public Management nor the Danish Ministry of Finance's view on the relation between politics and administration. I will not draw up "the democracy" or any other alternative norm in order to represent it as superior to New Public Management or the Danish Ministry of Finance. The interest of this article is sociological as it intends to withdraw from the present discussion of the relation Politics/ Administration; not to determine what is true, false, right or wrong in the discussion, but to question the discussion itself, its emergence, its construction, and its function in the political system.

Thus, the article engages in a general problematic issue, but with the $\mathrm{D}$ anish development as its specific subject. The issue is general in so far as it concerns all countries with a democratic constitution that has to separate politics and administration in order to make the democracy work at all. The article concerns all of the OECD countries especially, who have experimented 
with administrative reforms inspired by New Public Management throughout the 1990p. The subject is, as before mentioned, the D anish development. But as the Danish administrative policy to a high degree has found its inspiration in the OECD during the last twenty years, the following analysis may be interpreted as a case example.

The article raises three questions:

1) What type of difference is Politics/Administration, and what function does it have in the political system? D oes the difference refer to a boundary between two different systems, a political system and an administrative system, with their own separate logics, or is the difference an internal one in the political system?

2) How did it become an option for the Danish Ministry of Finance over time to politicise the relation between politics and administration in the way that it does? How has the semantic space of options for the politicising of the difference Politics/ Administration changed?

3) How does the politicising of the difference Politics/Administration by itself change the political system? Does the change on the semantic level bring on any changes in the system? The assertion is that the semantic development of the difference Politics/ Administration in the administrative policy of today results in a political system, which has become reflective on itself as political.

The article falls in four parts. The first part introduces the starting point of the article's strategy of analysis. The second part discusses the system character of the political system, and conducts an analysis of form of the difference Politics/Administration. The third part engages in the semantic history of the difference Politics/Administration in Denmark. The fourth and final part makes an analysis of differentiation, and concerns how the semantic development opens up for a change of the political system's self-observation in direction of reflectivity on the boundary Politics/Administration.

\section{Strategy of Analysis}

The article focuses on a difference, the difference Politics/Administration - not on politics and not on administration - but on the relation between them. Bearing that in mind I have chosen Luhmann's theory of systems of communication, as this specific theory is based on a certain constructivistic philosophy of difference.

The starting point for Luhmann is that society consists of communication and nothing but communication. Society is differentiated through systems of communication. The individual system of communication is auto-poetic, in the sense that it creates itself and all the elements it consists of. Therefore all systems are closed. They cannot contribute to each other with elements. Every system of communication has its own "logic" and its own "language," therefore it can only communicate with itself. D espite their communicative closeness they can constitute an openness concerning information. The systems can observe their environment and they can be sensitive about their environment. However, as the environment is an element within the system this is an internal construction in the communication. Systems of communication can thus observe each other but never communicate with each other. Systems theory is from this point onwards defined as observations on how systems of communication observe. The basic analytic of the theory of systems is thus a second order observation.

According to Luhmann's reasoning I have chosen and developed three complementary strategies of analysis, which shall be accounted for shortly. The three strategies are: analysis of form, analysis of semantics, and analysis of differentiation. ${ }^{1}$

\footnotetext{
${ }^{1}$ For further discussion and comparison of these strategies of analysis with other discursive strategies of analysis see: Andersen, N.A., 1999: Diskursive analysestrategier, Foucault, Koselleck, Laclau, Luhmann [Discursive Strategies of Analysis, Foucault, Koselleck, Laclau, Luhmann; in Danish only], Nyt fra Samfundsvidenskaberne, Copenhagen.
} 


\section{Analysis of Fom}

Luhmann's analysis of form corresponds to a large degree to what Jacques Derrida means by deconstruction. By deconstruction I mean an operation aimed at dismantling differences by showing that they are not differences at all, which means that the "line" between two elements in a difference cannot be sustained in a manner, which isolates the elements from each other. The non-difference of the difference (if you like) as presented by the deconstruction is at the same time a presentation of the mechanisms or games that are present in the making of the individual difference. It is a matter of seeing the difference as a mechanism in a game that creates meaning. There will often appear to be a hierarchy between the two elements in a difference. One of them, so to speak, dominates the other. By deconstructing the difference the relation between the two will often be changed, thus creating a situation where what seemed natural before will turn out to be an issue of dominance.

Accordingly, the purpose of the analysis of form is to analyse the difference in regards to the logic it installs. Luhmann calls this logic the constitutive paradox of difference. This paradox may be uncovered as the unity of the separation of the difference; the difference's third, in fact. A difference thus installs a paradox in the communication, wherefore the communication can be viewed as the continuous unfolding of the paradox. The communication is left paralysed if it "discovers" the paradox it is based upon. The unfolding of the paradox can, therefore, be seen as a strategy of deparadoxation, which means the communication's continuous attempt to hide its own paradoxical constitution. For example, the System of Justice cannot live with the fact that it is not able to determine whether the difference between justice and injustice is just, and the System of Justice, therefore, continuously develops new suggestions for basic norms.

However, Luhmann's concept of difference is different from Derrida's. It is not based on language and semantics but on a mathematical idea of difference founded by G. SpencerBrown and revised by H. Von Foerster and Gotthard Günther (Spencer-Brown, 1969; Von Foerster, 1981; G ünther, 1976). The fundamental idea is that all observations are connected to differences, not to a conscious subject. Luhmann defines observation as a particular difference-making operation: we cannot observe anything in the world without marking one side of a difference (Spencer-Brown, 1969, p.1). What is being observed is controlled by the particular difference. But the one, who observes, does not see the difference that determines what he can and cannot see. Basically, analysis of form is about describing this difference and its paradoxical unity.

Apart from this general concept of difference I shall distinguish between boundary and reentry as two "particular" kinds of difference-making operations.

Actually, any observation creates two differences at the same time. One of them is the difference the observation makes between the marked inside of the difference $(\mathrm{m})$ and the unmarked outside (i.e. it is a man, therefore, not a woman). The sign for this difference is: $m$

The other difference is made with the observation as the difference between the observer and the observed. This difference is the boundary between the system and the environment, which is called The Baundary of Meaningby Luhmann. Neither the system nor the environment exists ahead of the observation. On the contrary, it is the operation of observing that creates both of them. The boundary of meaning is the horizon of meaning of the system of communication. The boundary of meaning determines that meaning outside the system is created on other conditions than inside. Therefore, the condition of talking about a boundary between politics and administration is that both of them can be identified as individual systems with their own boundary of meaning. That means that meaning is based on some fundamentally different conditions in the political system than in the administrative system; thus politics and 
administration cannot communicate with each other. Consequently, to argue that the issue at hand involves a boundary of meaning may be a very demanding statement.

The final kind of difference I shall introduce is what Spencer-Brown calls re-entry. Reentry concerns how a difference is sometimes copied and reintroduced in the space the difference has created itself through its cleaving (Spencer-Brown, 1969, pp.69-76). A reintroduced difference is a difference that occurs in the space, which was created by the difference (Luhmann, 1993a, p.484). It may sound a little odd, but it is a common phenomenon. One example is the separation of the political communication in government and opposition. If we watch the news, we can see daily how this difference is reintroduced on both sides of the division. For example, we can see how, when viewing the government, it contains both a governing wing and an opposition. Often, we can see that the opposition contains both a governing opposition and an opposition to the governing opposition. If we take a look at any government and its internal wings we will be able to see that they, at the same time, must have the same relation to the same environment (us = the government, them = the opposition), but they also construct their own individual environment, for example, their own group of friends. Furthermore, they also construct each other as environment. The opposition in the government constructs the government itself as its own environment. On one hand, this increases the government's possibilities of communication and its sensitivity to the environment, for example, by providing the government with contact to more groups and issues. On the other hand, it installs also a paradox in the system as re-entries at the same time are identical with and different from the system, and that the system can never determine which one is the re-entry (copy) and which is the original. Does the opposition in the government or the government in the government represent the "right" line; the "genuine" government?

\section{Analysis of Semantics}

Where Luhmann's analysis of form corresponds to Derrida's concept of deconstruction, the analysis of semantics corresponds to Michel Foucault or Ernesto Laclau's discourse analysis.

Where deconstruction is supposed to open up the political space by dismantling central differences such as Freedom/ Power and present the logic of their way of reasoning, the discourse analysis is, subsequently, supposed to pursue the unfolding of these logics in historically concrete discursive struggles for hegemony.

Correspondingly with Luhmann: where the object of analysis of form is to present the paradoxes, which central differences such as Right/Wrong and True/False are based on, the purpose of analysis of semantics is to study the creation of these paradoxes and the following relevant historically concrete attempts to de-paradoxate the paradoxes through continuos attempts to fixate the meaning of the particular difference.

Thus, Luhmann distinguishes between a system of communication and semantics. Semantics are defined as special structures that connects communication with communication by providing different kinds of meaning, which the system of communication treat as worthy of preservation (Luhmann, 1995, p.282). Semantics are the reserve of generalised forms of differences (e.g. concepts, ideas, images, and symbols) that can be used in the selection of meaning in the systems of communication. Semantics are, in other words, condensed and replicateable forms of meaning that are available to communication. These generalised forms of meaning are relatively independent of the situation and obtain their concrete content in the communication that selects them (Luhmann, 1993b, pp.9-72). In short, the strategy of the analysis of semantics is about studying how meaning is created and attempted fixated and condensed in the form of new concepts, shifts in the concepts and their relations, including the replacement of the concepts' counter concepts etc. Nevertheless, this process is marked by struggle and involves what Foucault chooses to call productive power. Luhmann will, less sentimentally, refer to it as a process of construction. 
The relation between analysis of form and analysis of semantics can be illustrated like this:

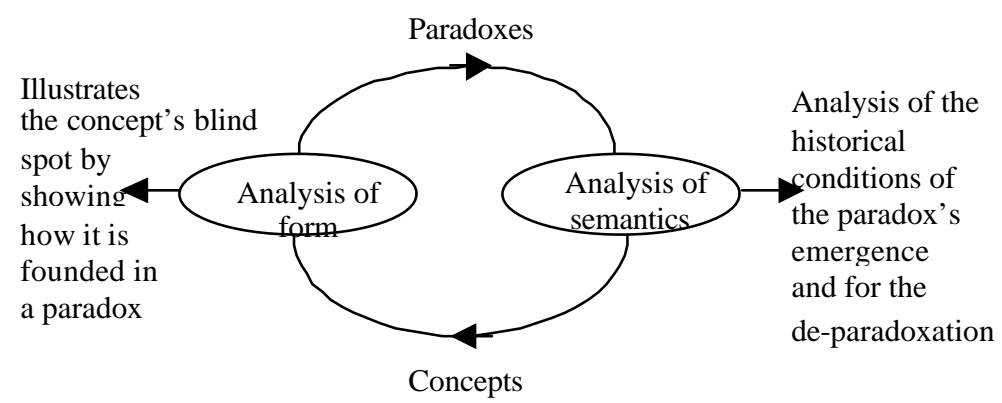

\section{Analysis of Differentiation}

Following the analysis of form and the analysis of semantics I make an analysis of differentiation. What comes closest to an analysis of differentiation, as presented by Luhmann, in the discourse theoretical tradition, is probably the analysis of inter-discoursivity. When discussing Foucault, this may be understood as discourse formations' mutual exclusion and, when dealing with Laclau, it may be interpreted as antagonistic chains of equivalence.

The purpose of the analysis of differentiation is to analyse the system of communication's unity of difference. This unity is called the form of differentiation; briefly, the analysis of differentiation can be described as an analysis of the similarities of the difference between systems, i.e. the similarity in the way in which the systems make themselves differ from each other, and the likeness in the way in which the systems construct themselves through the difference System/ Environment. The analysis of differentiation, therefore, tells us something fundamentally about the space of possibilities for the creation of communication systems.

The form of differentiation determines the systems' fundamental form of sensitivity to their environment, i.e. the basic manner in which the systems of communication let themselves be disrupted by their own internally constructed environment.

The relation between semantics and form of differentiation is that the semantic development always follows society's form of differentiation, which means that the condensation of meaning in concepts in various systems of communication follow each other as parallels. Luhmann calls it a joint transformation of society's semantic apparatus. Concerning the strategy of analysis, this means that the emergence of a new form of differentiation shows in a semantic rupture firstly. Inevitably, a new form of differentiation must show that a new semantic space of possibilities is being established. Thus, the analysis of semantics is the entrance to the analysis of differentiation. In this way the analysis of semantics is placed horizontally on the relation between sensitivity to the environment and the form of differentiation. It can be illustrated like this (Luhmann, 1993b, p.34):

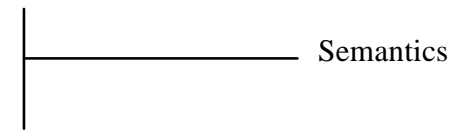

Form of differentiation 
The three analytic strategies and the questions connected to them can be summarised like this:

\begin{tabular}{|l|l|l|}
\hline Strategy of Analysis & Question & $\begin{array}{l}\text { The Strategic Analytical } \\
\text { Problem }\end{array}$ \\
\hline Analysis of form & $\begin{array}{l}\text { What is the unity of the } \\
\text { difference and what paradox } \\
\text { does it establish? }\end{array}$ & Why this specific difference? \\
\hline Analysis of semantics & $\begin{array}{l}\text { How is meaning condensed and } \\
\text { how does it bring about a } \\
\text { reserve of forms, i.e. stable and } \\
\text { partly common differences that } \\
\text { are available to the systems of } \\
\text { communication? }\end{array}$ & $\begin{array}{l}\text { When is meaning considered } \\
\text { condensed? } \\
\text { When does a semantics rupture } \\
\text { exist? }\end{array}$ \\
\hline Analysis of differentiation & $\begin{array}{l}\text { How do systems become } \\
\text { differentiated? } \\
\text { What is the similarity between } \\
\text { the differences of the systems? }\end{array}$ & $\begin{array}{l}\text { What is needed for the } \\
\text { similarity of the differences of } \\
\text { the systems to be pointed out } \\
\text { as a form of differentiation? }\end{array}$ \\
\hline
\end{tabular}

\section{An Analysis of form of the Difference Politics/Administration}

Let us now return to the article's theme: the relationship between politics and administration. I will begin with an analysis of form of the difference Politics/ Administration, and I will start off by assuming that the difference is not a boundary of meaning, but a re-entry. Whether this is a prosperous consideration or not cannot be determined within the analysis of form but only through the subsequent analysis of semantics. If we, through the analysis of semantics, can demonstrate the unfolding of the form, the analysis of form must have been on to something. Therefore, the strategic analytical problem of the analysis of form ("why this specific difference") really cannot be answered until the analysis of semantics has been completed.

In the following, I shall assume that politics and administration are not two systems but on the contrary that the line between politics and administration is a difference within the political system. This choice is, of course, disputable. Torstein Haaland, for example, argues that Norway during the $19^{\text {th }}$ Century "had two different systems - a political and an administrative one - marked by two different kinds of rationality or "logic"." (Haaland, 1998, pp.162-177). My opinion is that there do not exist adequate reasons to argue that meaning is based on other conditions in politics than in administration. It is not possible to find such a boundary of meaning.

I define the political system as a special system of communication characterised by a particular function and a particular code. The political system emerges as a functional differentiation, i.e. it stands out as a special communication, which differentiates itself from other types of communication in society, not by referring to a certain area or a special part of society, but by referring to a specific function. Political communication differs from other forms of communication as a system that appoints itself to function as a decision-maker on collectively binding decisions.

Compared to the political system, the State is nothing but the political system's semantics. This means that the State is the semantics which the political system attempts to describe itself through (Luhmann, 1990). The State is the political system's self-description.

As a system of communication the political system constantly distinguishes between itself and its environment, between what is political and non-political. This is made possible by using a binary code. The binary code marks the political system's boundary of meaning. Before the 
break through of democracy, the code of the political system was To govern/ Being governed. The code is a code of preference with a positive and a negative side to it: it is better to govern than being governed. In the area of political communication the world is divided in two, the governing and the governed. The political system secures its identity by connecting to one side of the code or the other continuously.

With the breakthrough of democracy the top of the political system becomes divided in two, i.e. the positive side of the code (governing) becomes divided between Government/ Opposition, where it is always better to be the government than the opposition. Thus, democratic and political communication are characterised by two codes: To govern/ Being governed and G overnment/ Opposition. According to Luhmann, democracy is exactly the unity of the difference Government/ O pposition. This means that all democratic, political communication connects to one of the sides in the two differences. Subsequently, politicising means to subscribe to either of the two codes of politics.

The division of the political system's top between government and opposition subsequently has great consequences for the space of possibilities of the political system, and the distinction between politics and administration is one of them. Before the division of the political top all administration was organised with the purpose of gaining the power. The power of the State and the power of the Administration of State were the same thing. There was a constant struggle for the power of the Administration of State and for the power of the local communities, e.g. the nobles, the church and the guilds. An example of this is the articulation of the occupation of office during the absolute monarchy in D enmark. During this entire period there was a constant struggle between the absolute monarch and the leading officials for the right to appoint new officials. Being in position to appoint officials meant possessing the power of the administration, and having the power of the administration meant possessing the power of the State. To the very end, the absolute monarchs fought for the right to appoint officials, and they always made sure that the appointed officials were loyal to the king. The officials were meant to know that they owed their appointment to the king himself (Jensen, 1987). After the division of the political top the matter of office becomes articulated in a totally different manner. The officials are no longer appointed with the aim to sustain or conquer the Administration of State and thereby the power of the State. It is attempted to make the appointments objectively, just like the official's skills are regarded separately from his personalities. The precondition for democracy is, amongst others, the development of political parties, which are capable of surviving the transformations from the role as governing to the role of opposition and vice versa. But the precondition is also that the administration implements the legally decided policy with loyalty, and that it is not directly persuaded by different political interests. Thus, the way to the Administration of State goes through the power of the State. This is here we get the distinction between politics and administration, or as it is stated in the $\mathrm{D}$ anish Constitution, between the juridical and the executive powers.

In this connection, the most important is that the difference Politics/ Administration does not indicate the outer boundary of the political system. The difference is a difference inside the political system of communication - not a coincidental difference, but a difference that is necessary for the reproduction of the political system's democratic form (the unity of government and opposition). Without a distinction between politics and administration, and between juridical and executive powers the political struggle becomes a struggle for the direct conquest of the Administration of State, which would cancel the division of the political top and thereby the meaning of the difference $\mathrm{G}$ overnment/ O pposition.

The difference Politics/Administration is not a boundary of meaning, but a reintroduced difference. The difference between what is political and what is non-political is copied and reintroduced in the political communication. 


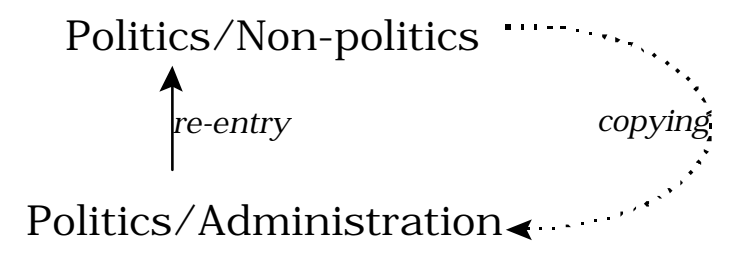

In the reintroduction, the unmarked outer side of politics (non-politics) is marked as administration. This means that Politics/ Non-politics becomes Politics/ Administration, i.e. it becomes a difference between what is really political and what is less political. The difference Politics/ Non-politics is copied and reintroduced as the difference Politics/Administration on the inside of the space created by the difference Politics/ Non-politics, and this way the difference becomes part of its own unity. Thus, it is simultaneously the same and not the same difference. It can be illustrated this way:

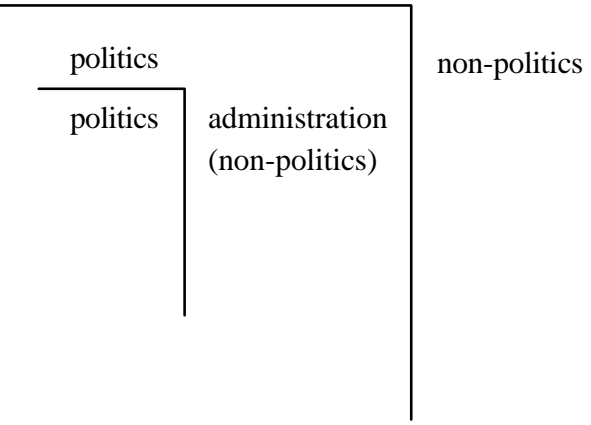

Thereby, the political system faces a paradox in which the political and the administrative basically remain indefinite. When "administration" becomes separated out insidethe political, it follows logically that it cannot be separated clearly fromthe political at the same time. The problem is the "difference in the same," i.e. the necessity of treating the administration as something different from politics while the administration is political as well at the same time. The problem consists of the necessity of treating the same difference like it was a different difference. The paradox is insoluble, but can and mst be handled through de-paradoxation and unfolding.

The most obvious way to solve a situation, where the paradox is in the way of political communication, is a continuous unfdding of the paradox. The political system is forced to unfold the paradox of the reintroduction and the manner in which the system unfolds the paradox is through still more reintroductions on both sides of the difference Politics/Administration. In this way, for example, the environment of an administration always appear as political (seen from the point of view of the administration), even though the 'same' administration, from the point of view of a hierarchically subordinated organ, naturally appears as this organs political environment. However, the handling of the paradox through unfolding is only successful if the unfolding does not appear to be what it is during the political communication, namely a reintroduction. Deparadoxation can be described as a strategy on how a re-entry can be hidden and forgotten and it can, for example, consist of a "naturalisation" of the environment (Luhmann, 1993c; Andersen, N.Å., 1996). For example, our administration from earlier can begin to describe its political environment; it might characterise it as a structural framework, characterise it in time by, for example, describing how politics seems to move more and more in one specific direction, describe politics as something that presses on from the outside with the necessity of the imperative etc. At the same time the administration becomes naturalised as an administration. Facing these naturalised political environment the administration has no doubts about itself as administrative and as non-political. The administration becomes identical with itself as administration in negation of the political - at least as long as the de-paradoxation is successful in hiding the paradox. The paradox that the administration is always political as 
well, disappears from field of vision of the communication. It is forgotten that it concerns a re-entry and the oblivion opens for the continuation of the political communication (Esmark, 1998).

What is actually politics and what is administration is not possible to determine. It always depends on which system's point of view we see it from. In a scientific second order observation, we are still not able to distinguish the original from the copy simply because the original is a copy already by definition; there is no 'first time' difference between politics and non-politics; the re-entry of Politics/ Non-politics as Politics/ Administration is always a reentry already.

I will, briefly, give some examples of re-entries of the difference Politics/Administration. The difference is, for example, reintroduced on the political side as the distinction between the party-political work and the party organisation, but it is also reintroduced as the distinction between cases of principle that, of course, belongs in the political area, and then the individual cases that never should have been made a political issue, but should have remained strictly administrative.

On the administrative side of the difference, the difference is re-entered in every single administration at all levels, e.g. as the difference between what is politically given for us, and the content we ourselves can decide to fill in the frame with. What can be characterised as the frame and what is content is not always obvious, leaving the decision-makers in the administration busy continuously. On the administrative side, the difference is also reintroduced as a difference between political and administrative cases. In the administration it is a constant problem, to determine which cases are administrative and can/ must be decided by the administration itself, and which cases it should refer to someone higher up in the hierarchy; in the political area. Furthermore: it is also a reoccurring problem for the administration to determine which cases are political to a degree that it must be avoided, first of all, that they become 'politicised.' The cases can be so politically "explosive" that they, more than anything, must remain administrative and dealt with as such. However, it becomes a problem for the administration how to present the cases as objective, avoid expressions that trigger the politicians, in short, as far as possible, to keep the cases at a distance of the political world.

The difference Politics/ Administration becomes of interest also when responsibility is being divided. Again the difference re-enters on both sides of itself. On the political side, for example, there is a distinction between political responsibility, which incorporates political consequences, and administrative responsibility, which incorporates disciplinary consequences. On the administrative side, there is a distinction between our responsibility for executing and implementing decisions, and their (political) responsibility of taking initiative, acting, and making decisions.

But all these re-entries of the difference are all political in the sense that they are part of a political communication, which forms the code Government/ Opposition. It is only within the political that the difference between what is a matter of principle and thereby political, and what is an individual case and thereby administrative, between what is a political decision and what is just a practical implementation of a decision etc. can be made. The place from where an administration draws the line between politics and administration is always the political system. It is always a line of political balance, but the never-ending operation of re-entries hides this fact. It is a neessary seme. It is precisely the never-ending re-entries' function to hide the source of the difference, i.e. the paradox of the difference. If the administration in its administrative operations was aware that its operations were political all the time, it would imply a simultaneous marking of both sides of the difference Politics/ Administration, which would be a cancellation of the difference between politics and administration - and that would 
be a threat to democracy itself; in the meaning of the unity of the difference Government/ Opposition.

No matter where we enter the political system, we shall find the difference Politics/Administration and never in the exact same shape. Simultaneously, it is always the same, yet somehow another difference. There is never total coherence between the re-entry of the difference on the political side and the re-entry of the difference on the administrative side. It can never mean the exact same. The difference will always be determined locally, but the fact that the difference is local will always remain concealed. Therefore, the difference Politics/Administration is not the political outer borderline. Furthermore, it can never ever become one clear line of division within the political area either, and it never will be.

\section{An Analysis of Semantics of the Administrative Policy as Politics about the Difference "Politics/Administration"}

If my analysis of form of the difference Politics/ Administration is correct it must appear semantically in the continuous development of new strategies of deparadoxation, in still more new ways of condensing and fixating the difference Politics/Administration.

But what would happen, then, if the political system not only (continuously) operates with the difference Politics/ Administration alone, and emphasises first one side of the difference then the other side of it, but frames it and makes it the subject of political communication? What will happen if the difference, at one and the same time, is the subject of politicisation and the difference that builds the frame for political observation of the difference?

Another strategy of analysis must be introduced now. We move away from emphasising the difference Politics/Administration as a fundamental re-entry in the political system to emphasising the historically varying semantics, which the operation of re-entry has to its disposition. That means which exact meanings the difference Politics/ Administration is being given through history. We move from analysis of form to analysis of semantics. This part of the article's initial thesis is that the re-entry of the difference Politics/ Administration creates a paradox, and that the continuous deparadoxation, which the political system is forced into subsequently, appears as a constant semantic renovation of the difference Politics/ Administration. The following part will focus on the condensation of certain forms of meaning regarding the difference Politics/Administration. In the subsequent part, I shall discuss how the semantic development influences on the political system's possibilities of relating to itself, i.e. the political system's form of differentiation internally.

\section{Administrative Law and Administrative Simplification}

The semantic development of the difference Politics/Administration was initiated already with the discussions of The Constitution in the last century, and came to unfold itself in the Administrative Law. At the same time, we see the distinction discussed in individual legislations such as administrative directives, which specify the premises under which the administrations should administrate. However, the development of the difference does not really accelerate until the Administrative Law is introduced as a separate law.

Compared with Germany and Norway, the Administrative Law in Denmark was developed relatively late. The first feeble dispositions to enact an Administrative Law appear by the end of the $19^{\text {th }}$ Century. In 1870, however, composed and presented in lectures as early as 1864, "D en D anske Statsforvaltningsret" ("The Danish State's Administrative Law") by Carl Georg Holck, professor in jurisprudence, is published. The publishers describe the book as the first complete and systematical publication of the Danish State Administrative Law. In retrospect, the book becomes of importance primarily by setting out the Administrative Law as an independent issue, as regarding the constitutional law, under the generic term "the state law". 
Using Holck's own words: "The object of the Administrative Law is foremost to present the activity of the State for the different purposes of the State; thus it presents the State's action while the constitutional law presents it in resting." (Holck, 1870, p.2). The distinction between politics and administration has been "sent out in the corridor" in Holck's definition of Administrative Law as the question of politics, narrowly implied as the legislative powers, is referred to the constitutional law. Therefore, the Administrative Law is defined as "The doctrine of the arrangement of the executive powers and the activity of these in the different purposes of the State, and in conformity with this designated Administrative Law" (Holck, 1870, p. 2).

In 1893, the book "Om Afgørelsen Af Tvistigheder Med Forvaltningen, Særlig Om Administrative Retter" ("Concerning Determination of Disputes with the Administration, Especially Concerning Administrative Laws") by Johannes Ussing is published. With this book, Ussing obtains the juridical doctors degree. In relation to Holck's book from 1870 it represents an important shift in the view on the problem of the Administrative Law. With Ussing, the distinction between a Constitutional State and a Police State is introduced in Danish Administrative Law. By Constitutional State, Ussing means law enforcement that emanates from recognition of the inviolability of the citizens' private sphere of jurisdiction without pursuance of existing law (Ussing, 1893, p.3). The question, which becomes essential for the Administrative Law to answer, is: How to solve the dispute that may emerge between the administration and an individual person. Ussing states the question as a contrast between the public interest and the interest of the individual. Ideally, the public interest should eliminate that any real dispute between the administration and the individual would emerge. For Ussing, the problem is that 'the public interest' is a concept, which is hard to determine in certain cases and therefore will be influenced by persons, political parties, and the mainstream of time. For Ussing the object is, therefore, to be able to determine disputes between the administration and the individual without references to the public interest. In short, the public interest is problematic as a juridical concept because it cannot be separated from politics in its concrete determination. A dispute, which is settled with reference to the public interest, might very well risk having been a political decision: "The more energetic the administration works for an assignment the more probable this one-sided claim of the public interest versus the often illegitimate individual interests becomes." (Ussing, 1893, p.10). The problem is how to establish the frames of the independent administrative settlement; the settlement free of political influence.

In 1924, the, probably, most important work on D anish Administrative Law before World War II is published: Poul Andersen's doctoral dissertation "On invalid Administrative D ocuments with Special Reference to Sources of Invalidity." It is a juridical dissertation that connects with the juridical code Justice/ Injustice and it indicates, first and foremost, the reflective side of the code (injustice) by engaging in the criterias under which an administrative document can be claimed to be invalid. An administrative document is here defined as a onesided statement of a certain juridical binding content from an administrative organ (Andersen, P., 1924, pp.22-). Now, why is this relevant? It is relevant, because politics is a considerable source of invalidity. Politics occurs as a more or less central aspect in all the sources of invalidity that Poul Andersen states (Andersen, P., 1924, pp.77-88). This means that politics plays the part of "injustice" concerning administrative documents in contrast to the independent administration, which plays the part of "justice."

Another discussion is conducted simultaneously with this dawning debate concerning Administrative Law. It involves how the public administration can be simplified in order to obtain savings on the budget. In 1921, the Saving Commission is set up. Here, administrative simplifications are only one aspect of the more general cuts in the budget. Following the setting up of TheAdministrativeCommission of 1923 the focus is put on a simplification of the administration. The simplification of the administration is, however, addressed from two sides, even though the Commission never becomes aware of this. One side is based on the 
ideal of limiting expenses and rationalisation. In fact, administrative simplification means rationalisation, for example, when the Commission considers turning rationalisation over to an independent administrative council. The other side is the law on administration. Here, administrative simplification indicates the positive side of the juridical code confronting "injustice," here as heterogeneous and inconsistent legal provisions. The two sides are intertwined especially in the discussion of the relation between the juridical power and the administration. The connection of the two is a simplification of the administration engaged through improved juridical procedures and an equally better co-operation between the legislators and the administration. Among other things, a proposal to establish a juridical council and a juridical office assigned to co-ordinate and simplify legal provisions is posed (The Administrative Commission of 1923, 1924; Sachs, 1925). However, one minute, the administrative simplification means spending cuts and rationalisation, the next, it means transparency in the administrative laws. There is an ongoing oscillation between the two points of view, where the economising and rationalisation arguments are influenced by the fact that they do not have a their own "vocabulary of concepts," but has to rely on the concepts of law.

\section{The Rationalisation Policy}

After the war, the AdministrativeCommission of 1946 is established. The terms of reference of the Administrative Commission are wide, and include, among other things, public administration, decentralisation and rationalisation. From 1947, the Administrative Commission turns the question of rationalisation over to the Administrative Tribunal, which is established for the very same purpose. When the Administrative Commission is abolished in 1952, the Administrative Tribunal is installed permanently. Furthermore, the Administrative Tribunal is abolished in 1964.

In the first years of the Administrative Commission's lifetime, the ambition was an administrative policy, which thematicised also the basic premises of the administration, among these the difference Politics/ Administration. Both the question of public administration and the question about decentralisation frames the difference Politics/Administration and, thus, makes the difference the subject of politics. The object is a sharper separation of politics from administration, and the discussion reaches back both to the discussion in the Administrative Commission of 1923 regarding administrative simplification (Sachs, Aa., 1925), and to the dawning discussion in juridical law regarding the valid administrative document free of politics. Regarding the last of the discussions mentioned, politics are often identified with influence from political parties, and the ideal about a non-political administration is, thus, equivalent with an administration, that makes administrative decisions uninfluenced by political parties. Public administration is, in this regard, seen as an important means, because the best protection against politicising of the administration is seen as healthy public morals manifesting itself in a public critique of differential treatment of the political parties (Andersen, P., 1943, p.190). D ecentralisation was also seen as a means to a clearer separation of politics from administration. One of the large discussions treated of placing the continuous administration away from the ministries' central organs, and instead place it in directorates, local state organs and municipalities (Bredsdorff, J., 1951). In relation to decentralisation, the consideration of an effective administration, however, soon replaces the consideration of separation of politics and administration. In his archive studies of the Administrative Commission Niels Bredsdorff has, among other things, found reports of a discussions that anticipates the discussions of the 1960s about the relation between department and directorate, a discussion that fundamentally treats of the civil service's access to the minister (Bredsdorff, 1996). However, political conflicts prevented any greater official reform proposals and the work of the commission was depolitcised through the delimitation of the principled questions. Among other things, the Administrative Commission rejects proposals about public administration and refers them to the Constitutional Commission of 1946, which later again gives them over to the ordinary juridical work (The Administrative Commission of 1946, 1950, pp.12-15 and pp. 26-31). With the Administrative Tribunal of 1947 and its limitations to questions of rationalisation we get an administrative policy that is placed in the 
administration but at the same time have the explicit norm to be non-political. The object is a policy that can assist the administration with advice and consultation in the project of rationalisation. Typically it concerns administrative techniques, filing and organisation of casework.

The Administrative Tribunal thus assumes the difference Politics/ Administration but only indicates the administration-side. By marking it this way the Administrative Tribunal distinguishes between political policy regarding the administration and technical-administrative policy regarding administration. The last one mentioned presumes that the Administrative Tribunal can delimit the specific political in administrative policy. This is, of course, no simple task and has obviously been a pressing problem for the Administrative Tribunal. The problem has been presented most clearly in 1953 by Bent Christensen. Christensen sees the efficiency of the administration as the objective of the Administrative Tribunal. Efficiency means a rating of the relation between procedure and results. An efficient administration is subsequently one that uses procedures that leads to the best possible result with the least possible effort. According to Christensen, the efficiency consideration is developed in relation to private companies where it functions unproblematic, but "When the in this way specific concept is applied to the administration the problems shows. ... If regulations for the efficiency of the administration have to be made it is necessary to know what the objective of the administration is, and preferably so precisely formulated that the objective itself can be used as the scale of the grade of efficiency" (Christensen, B., 1953, pp.343-344). The problem is that the Administrative Tribunal cannot draw up objectives for the administrative operations on its own because that is a legislative, political, job. On the other hand, there cannot be given any acceptably precise objective for the administrative activity on basis of the existing law (Christensen, B., 1953, p.344). According to Christensen, the problem is insoluble unless the focus is on the single working units inside the administration, for example, that the accountancy in a specific department is made the subject of attention (Christensen, B., 1953, p.345). To keep the political out of the rationalisation policy the difference Politics/Administration re-enters on the administration side as a difference between the administration as a whole and the single working units, where the first is politically determined and the second is technically determined. Parallel to this difference the difference Politics/ Administration also re-enters as a difference between form and content (Christensen, B., 1953, p.357). According to Christensen the Administrative Tribunal can only engage in the form of the administration, which will say the procedure in the in the separate working unit, and not with the content of the administration, i.e. the object of the administration. The problem can be summarised as a dilemma: either we have an efficient rationalisation policy that arrogates to itself political rights concerning the object of the administration (and that, of course, will not do), or we get an administrative policy that is not especially efficient (but on the other hand non-political) that only observes the form of the administration in relation to the separate working units, and, therefore, do not pursue the objectives that cost the big money (Christensen, B., 1953, p.357).

What we get, then, is politics about administration that is placed in the administration and tries to delimit the political in the rationalisation policy.

\section{The Planning Policy}

From the end of the 1950s the narrow demarcation of the Administrative Tribunal only to concern itself with the separate working units becomes problematised. In 1957 The Labar Marke Commission approaches the Administrative Tribunal with the concern of making them discuss the problem concerning the administrative separation of a number of educations. The Administrative Tribunal rejects the problem by referring to it as a question of content, and thereby, a political problem. In 1959 the Commission of Tednicians makes a report. The commission points out a sectorial problem of co-ordination of the Technical Educations and writes that the problem cannot be solved through adjustments of the legal basis of the individual educations, but demands a larger administrative reform that can enable a continuous concurrence and planning of the individual educations in relation to a general 
sectorial consideration. The Commission of Technicians simply demands a new administrative commission that includes the content of the administration and that takes a stand on its planning problems. ${ }^{2}$

This comes with the AdministrativeCommittee 1960 (A60). A60 makes 5 reports all in all. The first one explicitly frames the difference Politics/ Administration; the following four implicitly treats the difference Politics/ Administration by focusing on the content of the administration. The first report is the very famous report, which formulates the so-called departmentdirectorate model. In the first report the main problem is formulated as "The growth of the administration has increased the need for central planning and for a continuous inspection of the development in the fields that are included in the separate administrative branches." (The Administrative Committee of 1960, 1962a, p.13). The unclear distribution of assignments between departments and directorates, where the departments have been overburdened with individual cases is pointed out as a problem that has complicated the planning. This way of formulating the problem frames the difference Politics/Administration and asks to where this difference should bee made. The new planning problems are identified as political problems. Therefore, they have to be placed close to the minister. Systematically the term 'ministerial departments' is used to underline their proximity to the political; the term 'ministerial directorates' is never used. The committee does not make the difference simply as a difference between politicians and civil servants, but as a difference that cuts through the administration in, on the one hand, a case considering administration without access to the minister (the directorates), and, on the other hand, a planning administration with access to the minister (the departments).

The following four reports concern the demarcation of the substance of the planning. It happens through the construction of sectors or problem fields. The general discursive figure in which the problems of the sectorial demarcation are formulated can be formalised like this: 1) Originally there was an administrative whole, 2) The development in form of an increase in the extent and complexity of the administration has brought with it administrative separation, 3) Thereby, the overall unity is lost by means of which imbalance and co-ordination problems emerge, and 4) The unity is reinstated through planning and unification of the administration in sectors. The first report is about the co-ordination of education and, therefore, deals with the question of how to demarcate an education sector, and under this, it deals with when a problem is an education problem, when an education is a problem of education policy and not, for example, a trade policy arrangement (The Administrative Committee of 1960, 1962a). The second and fourth reports are about the differentiation of a sector of labour market policy from the sector of social policy, and about the organisation of a new Ministry of Labour (The Administrative Committee of 1960, 1962b; The Administrative Committee of 1960, 1965; Andersen, N.A., 1995, p.150-178). The third report is about the misplacement of the law of customs duties in the Ministry of Trade and about how it, more naturally, belongs in the sector of taxation policy (The Administrative Committee of 1960, 1963). Finally, the fifth and last report is about the reestablishment of the administrative coherence in the Main Audit Agency (The Administrative Committee of 1960, 1966).

In the first report the difference Politics/ Administration is explicitly framed and a model for how the difference should be made as a difference between consideration of cases and planning is formulated. In the following reports the difference is no longer explicitly framed, but the difference is implicitly rewritten when it is discussed which problems belongs to which sector fields, and when these sector fields are given a new organisational structure that often, but not unambiguously, draws on the first report of the A60. One could say that the

\footnotetext{
${ }^{2}$ Teknikerkommissionen [Commission of Technicians], 1959: "Teknisk og naturvidenskabelig arbejdskraft", Betankning nr. 229 [Technical and Scientific Working Capacity, Report nb.229; in Danish only ], Copenhagen. For further examination of the conflict between the Administrative Tribunal, the Labour Market Commission and the Comission of Technicians see: Andersen, N. A., 1995: Selvskabt Forvaltning [Self-Created Administration; only in Danish], Nyt fra Samfundsvidenskaberne, Copenhagen, p. 50-53.
} 
difference is always an implicit part of the discussion when the Administrative Committee decides which administrative assignments, which policy problems, which institutions, and which interests are included and excluded, respectively, in a particular sector because the committee at the same time decides which assignments, problems, institutions and interests have which access to which minister.

What we achieve with the Administrative Committee of 1960, which continues with the AdministrativeCamil and later with the AdministrativeDepartment until the end of the 1970s, is a planning policy that is placed on the administration side, a policy that implicitly enacts the difference Politics/ Administration and seeks to do that in a non-political manner through the difference Politics/ O bjective over-all consideration.

\section{The Administrative Policy}

From the end of the 1970s, the administrative political semantic changes again. Already by the end of the 1960s, the way of viewing everything in sectors becomes problematised, because one sector is elevated above the rest of the sectorial units; the economy unit. It is brought to attention that the growth in the public sector creates considerable economic problems of balance (The Ministry of Labour, 1971). D uring the 1970s, a semantic, regarding the planning of planning, is developed. An assembling of the sectorial units was proposed into bigger unities, first and foremost as an economic whole. An overall, and above all long-term planning, which could produce a frame for the less long-termed sector plans, was constructed. In 1975, this idea culminated with the report "Planning in the Civil Services," which, on top of the sector planning, imagined the establishment of four centres of planning moreover a central centre of planning. O ne of the planning centres was established in the shape of the Department of Budgds The rest were never established (yet, they have been the starting point for several administrative-political strategies in the 1990s, for example, the Ministry of Co-ordination).

By the end of the 1970s, the idea of the planning of planning breaks down. It begins with difficulties in the collecting and preparing of the informations necessary to build a planning system, and eventually the idea emerges of rewarding the administrations, who pursues an active policy of adaptation contrary to the administrations, who pursue a passive policy of aversion regarding the debit side (Thygesen, I., 1980). In 1981, a new ideal is introduced concerning an adaptation-efficient administration that aims at removing barriers for the individual administrations' adaptation of themselves (The Department of Administration, 1982). Planning Account no. 3 and The Modernisation Programme underlines the rupture. The planning policy is determined explicitly, and a new administrative policy is beginning to take form in the horizon (The Planning Information Committee, 1984; The Minister of Finance, 1983). From then on, a new administrative policy is created concerning the entire public sector. It aims at increasing the public sector's ability to adapt itself by changing the public sector's borders. The traditional borders are seen as a barrier of adaptation. The boundary between public and private is explicitly put at stake, e.g. through statements concerning different forms of privatisation. The boundary between administration and the individual citizen is put at stake, e.g. in programs about service oriented self-management, simplification of rules, and de-bureaucratisation. And finally, the difference Politics/ Administration is put at stake also. Not only in one, but in many reports; not just in one, but in many sketched designs; not just in one, but in many themes, the difference Politics/Administration is framed and made the object of administrative policy hereafter. Contract management and leasings are examples of this. In this article, however, I will only emphasise on one single example, which is articulated more and pinpoints the problem more than most documents concerning administrative policy. The subject is the report by the Ministry of Finance: "A New View on the public sector," published in 1993.

Where A60 first and foremost was about introducing a differentiation between the planning part of the administration, with access to the minister, and the case-working part of the administration, without access to the minister, the publication "A New View on the Public Sector," is, to a large degree, about creating more freedom of action in operational decisions 
within the public sector, without political interference. For example, the report says: "The political responsibility is a fundamental premise in the public sector. But that does not necessarily show through direet political management. Direct political management is appropriate in situations where the political aims are expressed and where it becomes secured that the political decisions are followed up upon. However, regarding the majority of the public sector, the political management is inconsistent with the demands of quality. Here, the management must become more general and fundamental. Here, it is appropriate often more that the political management is supplemented with, or partly replaced by, other forms of management." (The Ministry of Finance, 1993, p.90).

Thus, we have to do with an administration (The Ministry of Finance), which frames the difference Politics/ Administration in order to get the administration's operational ability in focus, and the political issues in it withdrawn. The staging of the problem has several dimensions. Firstly, through a difference in time: "Traditionally, the public sector has been viewed on the basis of idea that the politicians can survey and manage the public sector in all its particulars top-down. This precondition is no longer in place and the renewal of the public sector must be made in the light of that. Instead, the heart of the matter must be the public institutions, who's leaders and employees shall supply the services and the quality, which the citizens, the trade industry and other industries needs. ... The management can no longer build on hierarchy and centralistic solutions. On the contrary, it has to build on principles of dialogue and co-operation." (The Ministry of Finance, 1993, pp. 6-7).

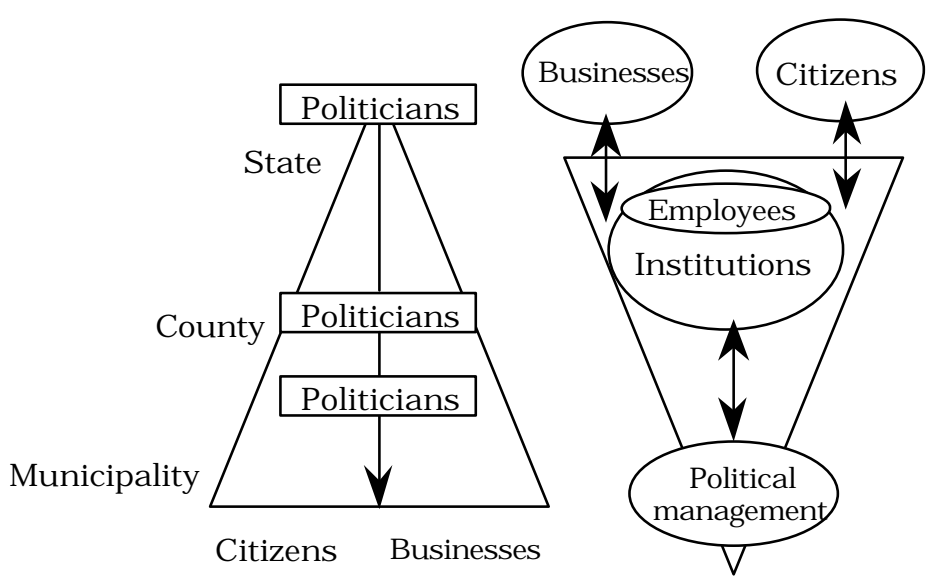

The Ministry of Finance illustrates the change with the above diagram, which is commented with the words: "The hierarchical model, which has been the carrying element in the public sector, is replaced by a model that, to a higher degree, is based on dialogue between the State, the municipalities, and the counties, and between the politicians and the institutions. The politicians' detailed management disappears in this model." (The Ministry of Finance, 1993, p.111). Thus, the report is highlighting a natural development with the Ministry of Finance as an instrument of time that is to say, an instrument of time that moves not only the boundary between politics and administration slightly to one side or the other, but turns the hierarchy upside down so that the political management is placed in the bottom in the future, and the relation between politics and administration becomes marked by dialogue rather than authority. Some places it is even underlined that the relation between politics and administration should be an "equal relation," even though the formal hierarchy is preserved as a "last resort" (The Ministry of Finance, 1993, pp.91-92).

Secondly, it is pursued to stage the difference Politics/ Administration as a problem of balance between over-steering and under-steering, which in that way is parallel with other problems of balance, for example between inflation and employment, or between import and export: "There is, namely, a risk of "over-steering" if major parts of the traditional management system is maintained in spite of the formal decentralisation and the involvement of the market and users in the management. ... On the other side, there is a risk for under-steering if the 
traditional system is removed without anything replacing it. The institutions can end up in a situation where they are managed neither from the top (politically) nor from the bottom (market and users)." ... "The renewal of the management in the public sector has the aim to give the necessary freedom of action to the institutions and their employees in order to work efficient in relation to the businesses and the citizens. To do this a clarification is needed of how far the political management should go and where the independent operation's responsibility begins. It should lead to the establishment of a new balance between political and operational responsibility so that both over-steering and under-steering are avoided." (The Ministry of Finance, 1993, pp.87-88)

The problem of balance is specified in a number of balances. In the top is the balance between politics and operations and following directly are the balances between conflicting objects and precise objects; and between carefully defined means and freedom of action; and between political leader and administrative and professional leader; and between staffing and local freedom of action regarding staff and, finally, between specified appropriations and framework appropriations (The Ministry of Finance, 1993, p.89).

How can it be, that a Ministry of Finance is able to deal with the contents of the administration as well as the politics, when the same situation was totally unthinkable in the Administrative Tribunal of the 1950s? Concerning A60, the answer was about the difference Politics/ The objectivity of the whole. Today, the issue is first and foremost that adaptation has become a value, has risen above politics. The political must not stand in the way of the public institutions' adaptation. That is why the institutions' freedom of action must be "shielded" from politics. Considerations concerning adaptation exist where the politicians must step back and enter a dialogue with the institutions instead of using the formal hierarchy. On the other hand, it involves high demands to the institutions, who cannot give up responsibility by referring to the political level. Limits for the administrations possibility of reintroducing the difference Politics/Administration with the intention of pushing responsibility upwards in the hierarchy are sought.

An example in "A New View on the Public Sector" is about quality. Among other things, it says: "The citizens have a right to quality. But quality cannot be secured through decisionmaking or laws and rules alone." (The Ministry of Finance, 1993, p.55). The citizens' right to quality is, thus, in one sense more important than the political. What we have here is a right that must not be violated by politics, but cannot be secured through politics either. Furthermore: "The responsibility for this (the quality) lies on the individual institutions. Therefore, the individual institution throug dalogue with the pditicians has to specify the aims that should be reached within the given framework, and in dialogue with the users create clarity concerning the users' needs and expectations." (The Ministry of Finance, 1993, p.56). The Ministry of Finance illustrates it as below: 


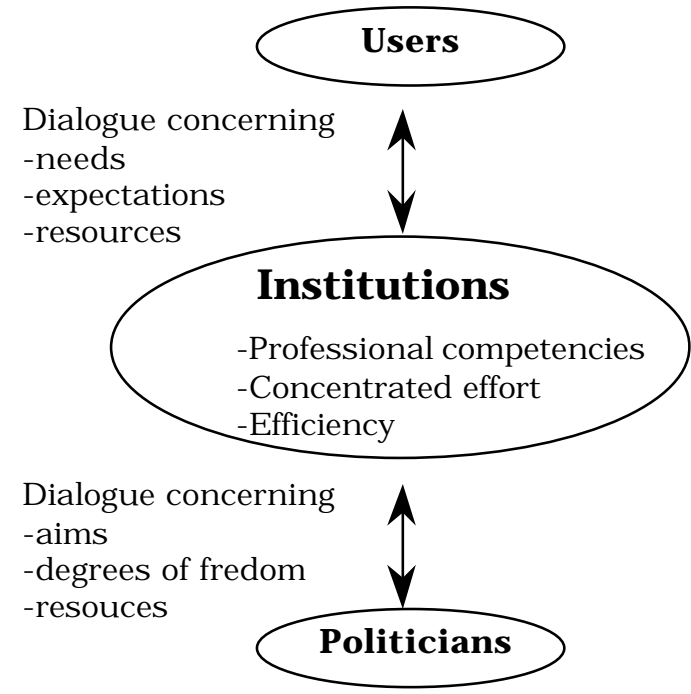

What we experience from the beginning of the 1980s, is an administration (The Ministry of Finance) that produces politics regarding the administration by framing the difference Politics/Administration, and by putting the difference expliatly at stake continuously in different reforms concerning contract management, concern management, the institutions' independence in the public sector etc. It is, among other things, a matter of shielding the administration from the political, getting the politics to draw back from the zone, which is named the "actually political" in order to give the institutions the freedom of action, but also the responsibility to adapt. Furthermore, it is an administrative policy that is accepted as being above politics and representing the highest value of that time; adaptation. This way, the administrative policy becomes mon-pditical to the extent that it operates with the difference politics/ adaptation.

\section{Conclusion: Differentiation of a Reflective Subsystem}

In the analysis of form, I suggested that we should consider the difference Politics/ Administration not as a boundary of meaning between two different communication systems, but instead as a re-entry of the difference Politics/ Non-politics on the marked side of the difference. This way, the modern political system can be seen as constructed on a paradox, where the difference Politics/Administration at one and the same time is the same difference and not the same difference as Politics/ Non-politics.

If this form bases a general dynamic in the political system, it means that the political system is compelled to unfold this paradox. Semantically, this must reveal itself in a continuous production of new forms of condensations of the difference Politics/ Administration. This is precisely what we have been able to demonstrate in the analysis of semantics of the difference Politics/ Administration. Since the beginning of democracy in Denmark; since the making of the constitution with its differentiation between juridical and executive powers; since the division of the top of the political system in government and opposition, we have been able to demonstrate the emergence of a long line of different semantics concerning the difference Politics/ Administration.

The Administrative Law, the rationalisation policy, the planning policy, and the administrative policy are four semantic deparadoxation strategies, which seeks to hide the paradox of Politics/ Administration with each of their different semantic tricks. 
In this way, the history of semantics witnesses different attempts to manage the paradox; very different attempts to create forms of meaning that handles the difference Politics/ Administration.

However, the semantic development seems to consist of much more than several successive strategies of deparadoxation. It is not just the emergence of new distinction between politics and administration, which is interesting. Furthermore, the interesting is not alone that for example, decentralisation and simplification are revitalised over and over again as concepts with changing counter concepts as, for example, Simplification/ Lack of legal rights, Simplification/ D ouble administration, Simplification/ Bureaucratisation etc. It is interesting also that the semantic ruptures seem to draw a shift in the differentiation of formin the political system. A shift that we can only see when we view the semantics of Politics/ Administration in the long historical perspective; a shift that cooperates the political system's ability to be reflective about itself. The politics' reflective relation to itself emerges through three steps and peaks with the administrative policy's semantics, which not only uses the difference Politics/ Administration, but makes a policy for how the difference ought to be. In other words a policy about politics; a second order policy. Level by level, the emergence of the politic's reflective relation to itself can be described like this:

The first level is announced with the rationalisation policy. With the semantics of the rationalisation policy only the administration side in the difference Politics/ Administration is marked. The difference itself, from where the administration can become visible in observations, which is the difference Politics/Administration, is not framed and made the subject of discussion, but is the blind spot of the rationalisation policy. We have observations of the first order, but not observations of the second order on how the political system makes its observations. The rationalisation policy's semantics opens up for the political system to refer to itself or its environment, but it does not open up for the system's possibility of seeing from where it observes itself. The rationalisation policy's semantics does not involve the possibility of the political system to question its own blind spots as limitations in its own system of communication and way of describing itself. In the rationalisation policy's semantics it is possible to operate with the difference Politics/ Administration, but it is not an option to problematise it.

With the next level, which is announced with the planning policy, the difference Politics/ Administration is framed. The difference is made the object of discussion only to be fixated in a new semantic figure (the department-directorate model) immediately after, which is not problematised later on. Hereafter, the difference is only treated implicitly, when area after area are analysed with sectorial problems of co-ordination as the starting point and rearranged in the image of the department-directorate model. This means that the difference Politics/ Administration is not the centre of attention and reflection, but it is treated implicitly by being pointed out by an external necessity (usually an imbalance in the unity). The planning policy's semantics gives us the possibility of self-reflection via external reference.

At the third level the administrative policy frames the difference Politics/ Administration. The difference comes at stake explicitly through a long line of politicisations. The relation Politics/Administration is problematised continuously in relation to a long line of areas and problems. It is continuously discussed what the rationale of the separation of politics and administration should be, and continuously the relation Politics/ Administration is made the object of choice. The administrative policy's semantics does not open up for reflection concerning the organisation of politics only, it opens up for reflectivity and for a reflection on how the difference should be discussed and made. I have called this self-relation a reflection on one self as reflective. 


\section{Politic's Relation to itself}

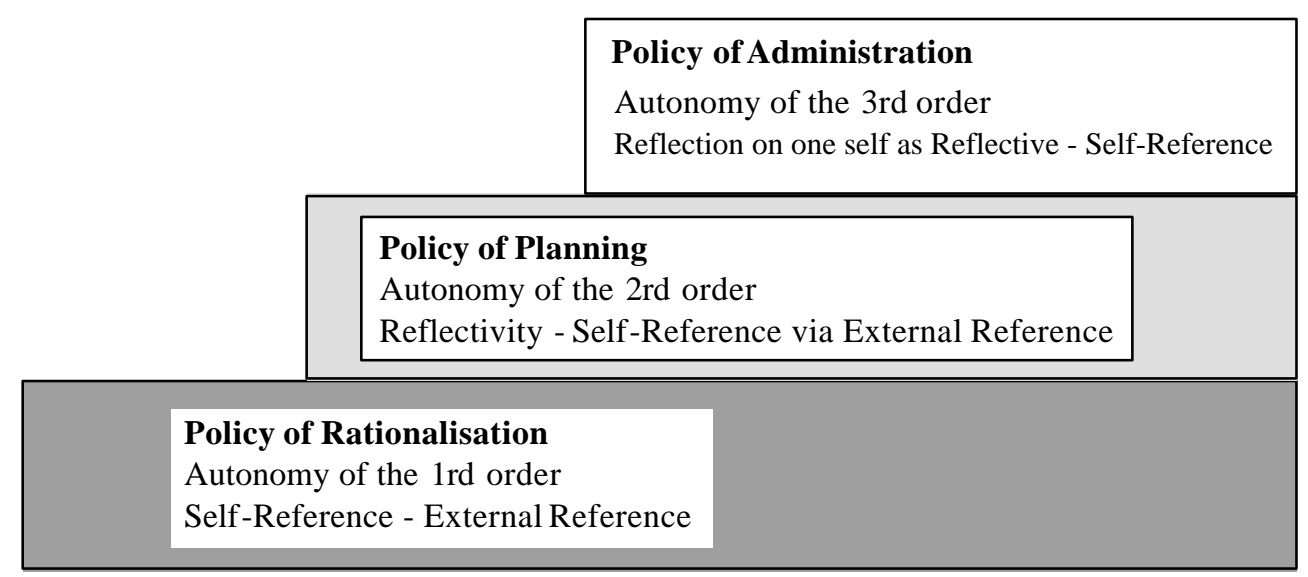

Thus, the administrative policy's semantics opens up for the political system to view itself, to see the difference Politics/ Administration, which rules the communication, and, thereby, making it a possible subject of choice and management.

However, in a system perspective we have to accept that there does not exist any place autsidethe political system from where it can see itself. For a system to be able to see itself (become visible in itself), it must divide itself between the observer and the observed (Spencer-Brown, G ., 1969, p.105). The establishment of the politic's reflection on its own semantics and differences is only possible, because a subsystem appears in the political, which assigns itself the right of being the one to describe the political system. In this subsystem of a higher order the semantic is the administrative policy, and the system consists of all of the communication that refers to this semantic. This system of higher order, which closes itself communicatively around the function of reflecting on the rest of the political system's basic differences, brings an asymmetry into the political system, because these higher orders' communications ascribes itself the right to be the active observer of the rest, who become the passively observed.

The administrative policy's higher order communications arrogate to themselves the right to describe the political system, to simplify it in images of the public sector, and to ascribe meaning to the political system and its many organisations in general. Consequently, the other subsystems can be viewed as having been ascribed meaning to. They observe themselves being described and simplified by others. Reports on "The Public Sector" are part of this simplification, where individual organisations are regarded as one kind, but also different types of ranking in the public institutions contribute to these simplified descriptions, for example, descriptions of "the best in the State" or public awards for quality. Balance sheets, staffing accounts, and bench marking as well are part of the schemata, which institutions in the political system must view themselves being simplified through. The observed ones get an identity ascribed to them through observations and descriptions, for example, in capacity of aims and functions, they get a position ascribed to them in relation to other institutions, a past and a future - often divided between threat and possibility - they get strong and weak sides ascribed to them, problems and solutions, responsibilities and expectations. All in all, the act of observation and description implies ascriptions, which also tie the observed ones to certain expectations.

Furthermore, the asymmetry consists of the existence of a place, which is not described, and is not observed, namely the place from where the observations are made. In this sense, the position of the observer of the administrative policy becomes a "non-place"; a place "taken-for-granted," which is not included by the power of description. It can also be explained in a more formal manner: the political system is only able to view itself by hiding behind a difference that it cannot see. This difference appears to be +Adaptation / -Adaptation. 
By the mid-80s, the higher order system of the administrative policy seems to have the Ministry of Finance as the absolute centre. Today, a long line of organisations have been build, which refer to the administrative policy and have arrogated to themselves rights to observe and describe the rest of the public institutions. Today, we find municipal and state organisations on all levels and in all sectors, which subscribe to the same semantics of administrative policy and arrogate to themselves the rights of an observer to make everybody else the object of observation. This is, for example, financial secretariats, offices of organisational development, management and personnel divisions, and then, of course, organisations such as The National Association of Municipalities $(\mathrm{KL})^{3}$ and The Forum of Personnel Policy ${ }^{4}$, which very much like the Ministry of Finance, views the administrative policy as a very central battlefield in the general struggle concerning the public sector's future. They all seek to be raised a step up as communication about communication, and they wish to install an asymmetry in the political system between the observer and the observed. In this sense, the higher order system of the administrative policy is a poly centric system with many centres, and the power connected with a higher order's reflective position is scattered (Andersen, N.A., 1995).

However, the Ministry of Finance still assumes an exceptional position among many of the organisations in the field of administrative policy. This is partly because the Ministry of Finance also have arrogated to itself the right of observing, describing, and ascribing by making general guidelines for personnel policies, legal frames for new wages, by being a negotiating part in all state contract agencies etc. (Andersen, N.A., 1995, pp.210-). Again, we have to remind that every single observation is an indication inside the frame of a difference. The observations we ascribe to the Ministry of Finance, and the observations the Ministry of Finance ascribes to itself, do not express any particular sovereign subject, but as any other observations they are connected with a difference; in this case to the difference +Adaptation / -Adaptation. As any other observer, the Ministry of Finance does not realise that it cannot see, what it cannot possibly see. Furthermore, even though the Ministry of Finance and others have arrogated to themselves the right to observe, describe, and prescribe the public sector, the Ministry of Finance does not observe from a position where it can represent "the unity." Firstly, one part of the public sector is placed outside of that particular public sector, which is the object of observation, in order to enable the observation. We have discussed this subject previously. Secondly, the political system of communication divides itself into subsystems all the time, which all distinguish between the system and the environment. If the world is the unity of the system and the environment and if the political system of communication divides itself into subsystems all the time, then there are manypolitical worlds. The political system's environment is in this way poly contextual and therefore cannot be represented in any kind of unity. The Ministry of Finance and others are able to construct "the public sector" as its own internal environment (through descriptions), but it will never be able to do a representation, which corresponds to the poly centric and poly contextual political system. The Ministry of Finance, the financial secretariats, and others have to put aside "the many worlds" for their own advantage constantly, with the risk of being reduced to "noise" instead of meaning in the observed parts, and with the risk of causing serious interruptions in the observed systems.

Thus, the administrative policy's semantic enables the subsystems in the political system to break away and arrogate to themselves rights as observers of the rest, who then become observed. But even though the administrative policy's semantic supplies forms of meaning that can frame the

\footnotetext{
${ }^{3} \mathrm{KL}$ is a non-governmental organisation representing the municipalities. $\mathrm{KL}$ has been given the competence to negotiate with the State on behalf of the united municipalities concerning a long line of subjects, for example, level of municipal taxation and municipal budget frames. Furthermore, KL is an import organisation concerning policy formulation in a long line of subject areas in regard to the municipalities.
}

\footnotetext{
${ }^{4}$ The Personnel Political Forum is a policy institution that consists of KL, The Association of Counties (ARF, which is an equivalent to the KL at county level) and the umbrella organisation for public employees as members. It formulates general strategies of personnel policy, initiates projects, and organises discussions.
} 
difference Politics/ Administration, the semantic does not change the fact that all political communication has to refer to the difference Politics/ Administration and that it has to unfold the paradox of the re-entry. This way, the subsystems (The Ministry of Finance, financial secretariats etc.), which subscribe to the administrative policy's semantic, mark the administration side themselves as the side from where they observe and conduct politics. Even though, the administrative policy specifically enables the political system to be reflective about the relation Politics/ Administration, administrative policy is defied as a political fact in the arrangement of the relation Politics/ Administration. It is discussed nowhere, how the emergence of the administrative policy itself changes the relation Politics/ Administration, and especially the "game" concerning the relation. The re-entry paradox is unfolded here also: only by defying the political, which means avoiding that the administrative policy is perceived as political politics, the administrative policy can avoid that the administrative policy's relation to the political becomes politicised also.

When observing, how the administration has been able to build limits for politics, it is tempting to conclude that the difference Politics/ Administration has been cancelled. In order to claim this, one would claim also that the power of the State can be conquered again via the state apparatus. That would be claiming that in reality democracy is cancelled. That is not the case, however. As never before, references are made to the difference Politics/ Administration. Previously, the difference Politics/ Administration was made by structural ties. The political aspect would, for example, exist as an external structure all the time in a civil servant's career. From the perspective of the individual communication, the difference appeared to be given externally. Before, the difference Politics/ Administration was an external tie to, for example, the administrative communication. Now, the difference has been moved into the administration, so that it is perceived no longer as an external structure, but, on the contrary, exists in every single administrative communication, which includes any administrative ruling as a question that has to be settled constantly. Now, one does not land on the administration side of the difference Politics/ Administration automatically, just because one enters a civil servant's career. Regardless of where one is situated, one can fall on both sides. The administration can take it for granted no longer that the administrative decision it makes is not a political decision. The administration can politicise no longer under the cover of a wealth of administrative prescriptions and routines. Not even the more or less court-like administrations, such as the Refugee Tribunal, can make political decisions concerning asylum any longer under the cover of administrative objectivity, but is instead constantly forced to consider whether it is concerned with politics or administration. That does not cancel the difference Politics/ Administration, but it to a large degree increases the tension concerning where the difference is made. Even administrative arguments, which are accepted as administrational arguments, contain the insecurity constantly that the administrative argumentation is rhetoric covering over politics in reality. The difference's character of structure has been deconstructed from within the political system itself and possesses the character of an inner dynamic instead. 


\section{Literature:}

Administrationsdepartementet, 1982: Betering1980, Copenhagen.

Administrationskommissionen af 1923 [TheAdministrativeComittæe f 1923], 1924: 2. błakning Copenhagen.

Administrationsudvalget af 1960 [TheAdministrativeCommitteof 1960], 1962: "1. betærkning", Beærkningnr. 301, Copenhagen.

Administrationsudvalget of 1960 [TheAdministrativeCommittee f1960], 1962: "2. betærkning.

Administration af Arbejds- og Sociallovgivningen, 1. del", Bearkningnr. 320, Copenhagen.

Administrationsudvalget af 1960 [TheAdministrativeCommittee 1960], 1963: "3. betærkning.

Administration af Told- og forbrugslovgivningen", Beærkningnr. 342, Copenhagen.

Administrationsudvalget af 1960 [TheAdministrativeCommitteef 1960], 1965: "4. betærkning.

Administration af Arbejds- og Sociallovgivningen, 2. del", Beæækningnr. 380, Copenhagen.

Administrationsudvalget af 1960 [TheAdministrativeCommittee of 1960], 1966: "5. betærkning.

Revisionsdepartementernes og hovedrevisionens forhold", Bezækningnr. 408, Copenhagen.

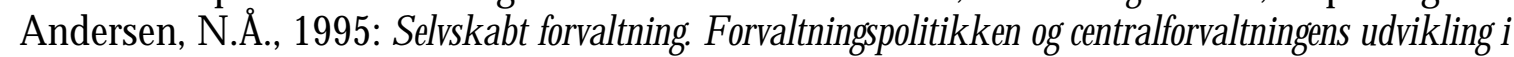

Danmark 1900-1994, Nyt fra Samfundsvidenskaberne, Copenhagen.

Andersen, N.A., 1996: Udiciteing-Når de privatebliver poditisk, Nyt Fra Samfundsvidenskaberne,

Copenhagen.

Andersen, N.Å., 1999: Diskursiveanalysestrategjer, Fourault, Kosdlekk, Ladau, Luhmann, Nyt fra

Samfundsvidenskabeme, Copenhagen.

Andersen, P., 1924: OmugldigeForvaltningsakter meel sarligt Henblik paa Ugldigheelsgunde[O n invalid

Administrative D ocuments with Special Reference to Sources of Invalidityl, A mold Buscks

Forlag, Copenhagen.

Andersen, P., 1943: "Politik og forvaltning", Nordsk Administrativt Tidssknift

Arbejdsministeriet, 1971: Pespoktivplanlaening1970-1985, Copenhagen.

Bredsdorff, J., 1951: "Rationaliseringsarbejdet indenfor stat og kommuner" , Hjort-Nielsen \&

Mikkelsen (red): Kommmal Aarbog1951, Copenhagen, pp. 701-771.

Bredsdorff, N., 1996: "Forvaltningshistorie og forvaltningsvidenskab - en undersegelse af efterkrigsåenes forvaltningshistorie og Forvaltningskommissionen af 1946", PhD-afhanding

Roskilde Universitetscenter.

Christensen, B., 1953: "Forvaltningskommissionen og Forvaltningsnærnet. Må og midler",

Nordisk Administratiut Tidssknitt, Copenhagen.

Esmark, A., 1998: "Forandringen stiger", COS-rapport, nr. 4, Copenhagen.

Finansministeren, 1983: Redegerelse af 30/ 1183 om regeringens program for modernisering af den offentlige sektor", Redegørelse nr. R 4, Fdketingstidende, pp. 2379-2392.

Finansministeriet, 1993: Nyt syn på den offentligesdktor, Copenhagen.

Forvaltningskommissionen of 1946 [TheAdministrativeCommission of 1946], 1950: 2. beæmkning

Copenhagen.

G ünther, G., 1976: Bëträgezur Gnundegungèner qperationsfähigenDialetic, Felix Meiner Verlag,

Hamburg.

Holck, C. G., 1870: DenDanskeStatsforvaltningse [The D anish State's Administrative Law],

Forlaget af D en Gyldensdalske Boghandel, Copenhagen.

Haaland, T., 1998: "Seculum Primum - D en norske sentraladministrasjonens første århundre

1814-ca. 1900", i Nordisk Administrativt Tidsskrift, Copenhagen, nr. 2, pp. 162-177.

Jensen, B.B., 1987: Udnæondsestetteni enevaddens magpditiskesystem1660-1730,

Administrationshistoriske studier nr. 12, Rigsarkivet, G.E.C. Gads Forlag, K øbehavn.

Luhmann, N., 1990: Pditical Thearyin theWdfareState, WdeG, New Y ork.

Luhmann, N., 1993a: "O bserving Re-entries", GraduateFaaultyPhilosqphyJaumal, vol 16, nr. 2.

Luhmann, N., 1993b: GesdlschattsstrukturundSemantik, Band1, Suhrkamp, Frankfurt am Main.

Luhmann, N., 1993c: "D ie Paradoxie des Entscheidens", i Vewaltungs-Ardhiv. Zeitshrift für

Verwaltungsidhre, Vewaltungsreht undV emaltungspolitik 84. Band, heft 3, pp. 287-299.

Luhmann, N., 1995: Social Systems Stanford University Press, Stanford. 
Planinformationsudvalget, 1984: Al denplanlaening- hvordanoghvorfor? Planreedegredse3,

Finansministeriet, Copenhagen.

Sachs, Aa, 1925: "Forholdet mellem lovgivningsmagten og administrationen”, Nordisk

Administrativt Tidssknitt, pp. 217-277.

Skjerbak, O.J., 1925: "Anmeldelse", Nodisk Administratist Tidssknift, Copenhagen, pp. 77-88.

Spencer-Brown, G .., 1969: Laus of Form G eorge Allen and Unwin LTD , London

Teknikerkommissionen, 1959: "Teknisk og naturvidenskabelig arbejdskraft", Beæækkningnn. 229,

Copenhagen.

Thygesen, I., 1980: "Flerniveau-planlærning af det offentliges udgiftspolitik", Indlagpå

Nationaldkonamisk Foreningskonferenceomdkonomisk planlaening 3/ 9, Copenhagen.

Ussing, J., 1893: OmA fogresenAfTristigheder MedForvaltningen, SaeligOmAdministrativeRetter

[Concerning D etermination of D isputes with the Administration, Especially Concerning

Administrative Laws], P.G. Philipsens Forlag, Copenhagen.

Von Foerster, J., 1981: Observingsystens Intersystems Publication, Seaside, CA.

\section{The author}

Niels Åkerstrem Andersen is associate professor at the Department of Philosophy, Politics and Management at CBS.

Telephone: $\quad+4538153664$

Telefax: $\quad+4538153635$

Email: $\quad$ aakerstrom@ cbs.dk 


\section{MPP WORKING PAPER SERIES}

1/2000 Betina W. Rennison:

Offentligledise? - en fartalingamfatallingen amNewPublicManagementog et altematiit studiepå vij...

2/2000 Ole Thyssen:

Luhmann og skriften.

3/2000 Erik Erno-Kjdhede:

Project management theory and the management of research projects.

4/2000 Kim Gortz:

Vidensledelsens iværksættere og vilkår - et essay om forførelse og forskel.

5/2000 Niels Åkerstrom Andersen:

Political Administration

1/99 Karsten Laursen:

Economic and Moral Sentiments - a philosophical approach.

2/99 Peter Holdt Christensen:

Viden og vidensledelse - nogle teoretiske overvejelser.

3/99 Anders Bordum:

Tanker om videnssamfundet.

Kim Mdler \& Flemming Poulfelt:

Perceptions on Management Consulting - myths or realities?

Erik Erno-Kjdhede:

The Coming of Age of the Danish Research Manager.

6/99 Sven Junghagen:

IT Strategies in Small Business - Application Contexts and Strategic Dispositions.

$7 / 99$

Peter Holdt Christensen:

Når viden skabes - John Dewey som teoretisk udgangspunkt for en analyse af vidensledelse.

8/99 Christian Tangkjæ:

Performing a Transnational Region - the importance of "Open House Strategy".

9/99 Helge Tetzschner:

Udvikling af et bachelorfag i entrepreneurship.

10/99 Henrik Herlau \& Helge Tetzschner:

Forskningsbaseret undervisningsudvikling $i$ Entrepreneurship på kandidatniveau.

11/99 Kenneth Husted:

Between Autonomy and Control: The role of industrial researchers' decision-making.

12/99 Helge Tetzschner:

Vidensledelse af sociale innovationer. 